\title{
EMORY HOLLOWAY AND THE QUEST FOR WHITMAN'S 'MANHOOD'
}

\author{
JEROME LOVING
}

IN AN ERA OF GAY RIGHTS ACTIVISM, Emory Holloway's most memorable study of Walt Whitman is not his Pulitzer Prize winning biography in 1926 or his more important and groundbreaking collection, The Uncollected Poetry and Prose of Walt Whitman (1921). Instead, it is unfortunately his vanity-press publication of Free and Lonesome Heart: The Secret of Walt Whitman (1960), in which he sought to demonstrate the poet's paternity and neutralize later biographers' growing concessionsbuilt upon Eduard Bertz's 1905 theory - that the poet was a homosexual. This fact was recently demonstrated by the publication of Joann P. Krieg's essay in the Walt Whitman Quarterly Review, ${ }^{1}$ of which more will be said at the conclusion of this essay.

A native of Missouri and a graduate of Hendrix College, Holloway (1885-1977) began his professional study of American literature at the University of Texas at Austin, where he completed a master's degree in English in 1912 under Killis Campbell, best known for his scholarship on Edgar Allan Poe. After teaching a year at the University of Texas, he enrolled in Columbia University and was first interested in Whitman by Professor John Erskine. By 1915 he was teaching at Adelphi College on Long Island, living in Brooklyn, and corresponding at least once a month with Henry S. Saunders of Toronto, who was also getting his start as a Whitman collector and bibliographer. Saunders, whose publications would include books on Whitman parodies and photographs, helped Holloway establish the first reliable Whitman bibliography in the 1918 Cambridge History of American Literature. Holloway also wrote the essay on Whitman for the literary history because Léon Bazalgette, author of the 1908 life of Whitman, was prevented from doing so because of World War I. ${ }^{2}$

The CHAL essay was not Holloway's first publication on Whitman, and indeed he had already collected enough material for many publications - had there been anything like a Whitman market for new material as there is today. His first essay on the poet was entitled "Walt Whitman in New Orleans," published in the Yale Review in 1915-an essay he researched in part while on his honeymoon in the Crescent City. ${ }^{3}$ The New Orleans research made its mark on Holloway's scholarship, for in it he became convinced that the poet was romantically interested in at least one Creole woman, alluded to in one of his 
editorials for the New Orleans Crescent in the spring of 1848. This suggested at least vague support for the thesis, first argued by Henry Bryan Binns in his 1905 life of the poet, that the twenty-nine-year-old journalist had "formed an intimate relationship with some woman of higher social rank that his own - a lady of the South where social rank is of the first consideration - that she became the mother of his child . . . and that he was prevented by some obstacle, presumably of family prejudice, from marriage or the acknowledgment of his paternity."4 Holloway, as we shall see, did not accept Binns' exact thesis-based in part on Whitman's old-age "confession" to John Addington Symonds that he had sired six illegitimate children, two of whom were dead, as well as one Southern grandchild. ${ }^{5}$ But the future biographer did become committed to the idea that Whitman was heterosexual-mainly because Holloway refused to attribute what he considered a deviate emotionality to the genius he found in Leaves of Grass.

Perhaps the best testimony to his attitude about the poet's sexuality can be found in his 1956 letter to Mrs. Ruth L. Greene, who started Holloway on his three-year search for John Whitman Wilder, supposedly the poet's illicit son. Upon reading Malcolm Cowley's remark in his New York Times review of Gay Wilson Allen's The Solitary Singer (1955) that "no trace" of the poet's illegitimate children had ever been found, Mrs. Greene challenged this assertion in a letter to Allen, who passed it on to Holloway. "The more I study this man of genius," Holloway told her, "the more I am impressed by how much beauty and courage and faith he was able to achieve in a life which must have seemed to him a continual struggle with lawless and often uncomprehended impulses within his sensitive soul." $\mathrm{He}$ was probably echoing what he had told an audience the year before at Queens College, where he had become chairman of the English Department when that school was formed in 1937. On the occasion of the hundredth anniversary of the first Leaves of Grass, he lamented the popularity of the thesis that Whitman underwent "a great emotional disturbance in the late 1850s" which resulted not only in the Calamus poems but an experience which ultimately defined "his central poetic output." Although Whitman's alleged homosexuality had become "the central fact of all enlightened Whitman biography and criticism" in recent years, Holloway said that he knew of one recent biographer, "a French scholar who is as indefatigable as he is acute, reads the same material, rating the conventional passages . . . as fairly as he does the more startling ones; and he finds what I found thirty-five years ago . . . , namely, that though Whitman was deeply disturbed and discouraged at this time, he had, before completing the manuscript of the [third] edition, already found his way through to a new grasp on life, a more realistic knowledge of himself, and a new joy in living and writing poems."7 
Holloway was apparently less comfortable with the reason for Whitman's emotional "slough" in the late 1850s than Roger Asselineau, the French scholar to whom Holloway is obviously alluding. Not too long ago I asked Professor Asselineau whether he had ever known Holloway. On January 28, 1993, he wrote: "Yes, I did meet Emory Holloway. I visited him one evening in his home. He was a very kind old gentleman, but very stubborn \& obstinately denying Whitman's homosexuality even with evidence of the contrary right under his nose. $\mathrm{He}$ [then] had in his possession the letters a soldier sent to Whitman which I published in 1949 in the Modern Language Quarterly under the title of 'Walt Whitman, Child of Adam?' He had generously given me permission to use them, but he was disappointed \& shocked when I published them, because he didn't want them to be used as proofs of Whitman's homosexuality. He thought I would have incorporated them into my book \& given them a different colouring. He refused to see the homosexual elements in them-But he forgave me \& sent me a copy of his Free E Lonesome Heart." (Incidentally, Asselineau told me in a subsequent letter that it took a long time to place his $M L Q$ essay. "No one wanted to touch my article," he told me. "Jay B. Hubbell, who was then editor of A[merican] L[iterature] dryly rejected it in 1947 \& I succeeded in publishing it in $M L Q$ only with Gay [Wilson Allen]'s support." $)^{8}$ The main difference between Holloway and Asselineau on the subject of Whitman's alleged homosexuality is that while each viewed it as a deviation from the "norm," Holloway refused to admit to the predominant existence in Whitman of what he evidently despised and perhaps feared.

The farthest he could ever go in accepting the possibility of Whitman's homosexuality he had long ago established in his 1920 Dial essay on Whitman's love affairs. It was also his argument in Free and Lonesome Heart: that the Calamus poems show that Whitman "retained in his maturity some of the sexually indiscriminate affection of childhood." And furthermore, "The artist is expected to pass in his imagination from the man's point of view to the woman's and back again at will.", Holloway was referring specifically to "Once I Pass'd through a Populous City," where he was the one to discover that at least one draft of the poem alluded to a male lover-"one rude and ignorant man." He had made that discovery three years before the 1920 essay but apparently told no one except his friend Saunders. "One curious MS interested me greatly," he said, referring to his visit to the Valentine collection, which had been previously closed to him. "It was the MS of 'Once I Passed [sic] through a Populous City,' a poem which has been used, as you know, to show that WW had a liaison in New Orleans with a woman whom he left there. Now, in the MS I saw, nothing is said whatever about a woman, though it is evidently the same poem. Instead we have 
'that youth' which is stricken out for 'One rude and ignorant man.' The last two lines are: 'But I remember I say only ["that youth" crossed out] one rude and ignorant man, who when I departed, long and long, / Held me by the hand, with silent lips, sad and tremulous.' Does this mean that the whole poem is not based on WW's personal experience, but is imaginary; or does it mean that he is concealing the nature of the attachment he is celebrating; or does it mean either?"10

Apparently, Holloway (who failed in his letter to Saunders to point out the male references in the second line of the manuscript) decided that the change in gender meant both. Although he printed the poem he found in 1917 in his Uncollected Poetry and Prose, he printed the "heterosexual" version when he discussed the poem in his biography. $\mathrm{He}$ did, however, give considerable attention to another Calamus poem, which Whitman later removed from both the Calamus sequence and Leaves of Grass as well. We know the poem by part of its first line, which reads: "Long I thought that knowledge alone would suffice me-O if I could but obtain knowledge!" The closing lines suggest the most difficult and revealing moods of any poem in Calamus:

For I can be your singer of songs no longer-One who loves me is jealous of me, and withdraws me from all but love,

With the rest I dispense-I sever from what I thought would suffice me, for it does not-it is now empty and tasteless to me,

I heed knowledge, and the grandeur of The States, and the example of heroes, no more,

I am indifferent to my own songs-I will go with him I love,

It is to be enough for us that we are together-We never separate again. ${ }^{11}$

This poem with its male pronoun is just as suggestive of the poet's homoerotic nature as the Valentine version of "Once I Pass'd through a Populous City," but Holloway perhaps allowed it because Whitman banned the poem from post-1860 editions of Leaves of Grass. In discussing the poem, the biographer argues that it was "born of a mood, and must not be unduly exaggerated; but it is an unhealthy mood, that leads the man away from the work of his life to accomplish nothing for himself or others. And it is the mood," he continues, "which predominates in these thirty-eight pages [of Calamus].... It is true that Whitman ... [ [thought] he was doing a high public service by encouraging a sort of friendship between men-equal in power to the romantic love-which would unite the nation by ties more real than laws or customs or institutions. But he should have realized from his own experience, as expressed in the poem just quoted, that when friendship becomes a jealous emotion rather than a shared ideal, a comradeship in work, it encounters psychological barriers to its socialization." "12

Following this discussion, Holloway turns with relief to "Song of Joys," which like "Song of the Open Road" celebrates the joys of the 
nation generally rather than intimately or particularly. The poem is also more spiritual than it is physical and celebrates not only the "joys of pensive thoughts" but the "joys of the free and lonesome heart." Thirty-four years later, of course, he would take this last line as part of his title for a book about "The Secret of Walt Whitman." To his credit, perhaps, Holloway returned in that book to the Valentine version of "Once I Pass'd through a Populous City." Yet even here he refused to accept the male references as evidence of Whitman's homosexuality. $\mathrm{He}$ argued that the version was not Whitman's final intention because the poem has always been grouped with Enfans d'Adam instead of Calamus. Possibly his best defense of the gender change in the poem is found in his Uncollected Poetry and Prose, where he speculates that Whitman first wrote the poem under the Calamus influence (producing the Valentine version) and then altered it to celebrate the romantic love for a woman (producing the Children of Adam version). He concedes here that Whitman may have made the change "in order to conceal the fact or the nature of that manly attachment," but he finally dashes that inference by concluding that Whitman desired "that the poem be understood, only in the light of its general, as contrasted with its personal, implications." 13 In discussing "I Saw in Louisiana a Live-Oak Growing" (1860) in Free and Lonesome Heart, Holloway states that Whitman betrays "a strong if short-lived yielding to the overmastering desire for the friendship of men" and that he "must have been under the influence of this bias" when composing the Valentine version of "Once I Pass'd through a Populous City." "14 This observation fits well with Holloway's belief that Whitman engaged in a lifelong struggle "with lawless and often uncomprehended impulses." 15

One unit of evidence that encouraged Holloway's lifelong commitment to the idea of Whitman's heterosexuality, or at least a "balanced" view of the poet's sexuality, consisted of two letters from a soldier or hospital steward written during the Civil War. Ironically, these were among the same letters Asselineau published in 1949 to argue for a homosexual Whitman. In 1915 Holloway told Saunders that he had purchased two letters from Walter R. Benjamin, the son of Park Benjamin, editor of the New World when Whitman worked there as a printer in 1841. Interestingly, what Holloway found in the letters was initially discouraging (making him, he said, "very sad") because he was disappointed to discover that Whitman had gone with prostitutes. The letters, he told Saunders, "seem to throw an unwelcome light on Whitman's relations with women of a low order during his stay in Washington." The letters were from Will W. Wallace, who addressed Whitman as "the Prince of Bohemia." Wallace had gone from Washington to Nashville in 1863 to take charge of a Union hospital as a steward (Tennessee remaining neutral as a "border state" during the war), and 
he told the "Prince" back in Washington that he had "five young ladies who act in the capacity of nurses-i.e., one of them is French, young and beautiful, to set your eyes on. Can you not visit us and note for yourself?" According to Wallace's next letter, Whitman replied that his own "Frenchy" had left him in a "deplorable state."16

Emory Holloway, the Saunders letters indicate, was an Emersonian Christian, who admitted to his friend that he had never gotten "much out of the life of Jesus until I had the courage to deny him any experience which in some degree I could not attain myself." The next month, he reported having something resembling a mystical experience, or an engagement with "cosmic consciousness," after reading Emerson "a good deal." 17 The son of a clergyman, he also lectured at the Plymouth Institute Bible Class in Brooklyn on at least two occasions in 1920, speaking on "The Bible as Literature" and "Short Stories of the Bible." 18 In his centennial lecture on "Whitman As the Subject for Biography," he suggested that "the ideal biography would be accompanied by an ideal autobiography, in order that the reader might know what manner of man is giving testimony and selecting evidence."19 Holloway is alluding here, not to all critics, but to those he felt had ulterior reasons for believing Whitman was a homosexual. "I do not mean all those who have accepted the idea that Whitman was a simple homosexual," he wrote in Free and Lonesome Heart, "but there have been gifted homosexuals among his interpreters."20

When Holloway had come across the Will Wallace letters in 1915, he wondered aloud to Saunders what the slang term "Frenchy" meant. He was reminded again of the question in 1920 when Saunders sent him photographs of woodcuts from a recent French edition of Calamus, an edition, incidentally, that he presumed appalling because of the homosexual suggestions. "If any of Whitman's poems ought never to be printed alone, these are they," he wrote. "They require the counter attraction of the Children of Adam if not the nature-sanity of the whole Leaves to prevent their having, for many errant minds, a vicious influence." The matter then reminded him of a recent conversation with H.L. Mencken, who had recently published his American Language (1919). In reading the book, he said, he had come across the word "Frenchy" in a footnote and subsequently asked Mencken directly about the term, hoping to shed more light on the Will Wallace letters. Mencken, he told Saunders, thought the term showed "with fair certainty that Whitman refers to a mistress (rather than a man) who practiced fellatio with him, which is said to be very exhausting. He does not believe that WW was at all homosexual, but he says he has no special knowledge on the subject." 21

Holloway was extremely conventional towards the subject of sex, not merely homosexuality. Just what drew him to Whitman in the first 
place is not easy to discern. His M.A. thesis at the University of Texas, entitled "The Feeling for Nature in American Poetry," does not treat or even mention Whitman. Its focus is on Bryant, Emerson, and Poe, and Holloway regards Poe as incapable of "moral poems." In his introduction, he affirms his belief that "the deeper the poetic nature, the more wonderful becomes its material counterpart," or, echoing Wordsworth, "even the 'meanest flower that blows' has power to awaken more reflective emotion in the modern subjective poet." 22 Yet when it came to the possibility of Whitman's homosexuality, he refused to view Whitman's "flower," or his Leaves, as a "fleur du mal." At most, the seeming homoeroticism was nothing more than an aberration in the poet's emotional makeup, which incidentally Holloway considered biological, not environmental or learned behavior. One Whitman critic recently suggested to me that a specialty in Whitman often leads to "guilt by association." In Holloway's case, this was apparently the problem. He was frustrated that Horace Traubel refused him access to his Whitman papers in Camden, but he would perhaps have been less chagrined had he known that Traubel was carrying on homosexual liaisons with at least one male member of the Walt Whitman Fellowship. ${ }^{23}$ In 1935 Holloway had planned to support Saunders and Clifton J. Furness, who had published the invaluable Walt Whitman's Workshop: A Collection of Unpublished Manuscripts in 1928, in a Whitman bibliography which would absorb the Cambridge bibliography of 1918 . When he discovered that Furness was gay, he told Saunders that he was free to use the 1918 material with Furness but, he added, "I think I would prefer . . . not to have my name on the title page. I suppose you wonder why I have changed my mind, but it will be sufficient to say, entre nous, that I have been influenced by things I have recently learned about Furness." Saunders dropped out, too, having edited in 1921 a collection of letters from various Whitman scholars arguing generally against the idea of the poet's homosexual orientation. ${ }^{24}$

In fairness to Holloway, however, we ought to reexamine the instance where Asselineau asserts that the evidence for Whitman's homosexuality was right under Holloway's nose. Whereas Holloway was "very sad" to learn from the "Frenchy" letters that Whitman had visited prostitutes, Asselineau argued in his $M L Q$ article that Whitman's statement to Wallace refusing his invitation to meet the Nashville nurses because his own "Frenchy" had infected him was simply "a white lie." Whitman, Asselineau says, "probably did not like the idea of going to Nashville and sharing the life of his dissolute friend, but he did not want to look timid, and the best strategem, of course, was to assert boldly that he had been quite busy himself in the same direction and that as a result of his excesses he would be incapacitated for some time to come." This appears to be a reasonable parry to Holloway's reading, 
but it may create more questions than answers. How well, for example, did the semiliterate Wallace know Whitman? His letter is quite informal and suggests that Wallace and the poet had enjoyed together such "Frenchified" women before. If Whitman was in any way actively homosexual, Wallace obviously did not know the poet very well. Yet how to account for this almost soldierly familiarity?

At the time of those letters, Whitman was writing several unanswered but highly affectionate letters to Thomas B. Sawyer, a soldier he had met in the Washington hospitals. In one of them, Whitman expresses the desire to live with Sawyer for the rest of their lives; yet he hopes that another soldier, Lewis Kirk Brown, will also live with them. ${ }^{25}$ Was this "the new city of Friends" the author of Calamus envisioned? It seems to me more indicative of the classical idea of male friendship gone slightly awry rather than a purposeful homosexual liaison. Both Edwin Haviland Miller and Asselineau find Whitman's desire for Sawyer "pathetic," but Sawyer himself appears almost baffled at Whitman's attention. Also only semiliterate, Sawyer apologizes for not living up to his "Prommice" to the poet. Later he again asks for the poet's forgiveness, saying "in the future I will do better and I hope we may meet again in this world." 26 One has to wonder just what all this meant before Oscar Wilde's 1895 trials and before the invention of the term "homosexual." Furthermore, evidence of the poet's homosexuality is today perhaps too quickly inferred in the face of the poet's direct testimony to John Addington Symonds that Calamus had no homosexual intent and that he had fathered six children. ${ }^{27}$

Holloway began to think seriously about a biography of Whitman in 1921 after reading The Answerer, a novel based loosely on Whitman's life by Grant Overton. With his Uncollected Poetry and Prose now with Doubleday (after being delayed by Yale University Press, which kept the manuscript almost a year before rejecting it, and by World War I, where he served with the American Expeditionary Forces in France), he told Saunders that it was his tentative plan "to try to produce a narrative biography, as distinguished from all the others in the field, which are primarily expository or interpretative.... I should reconstruct the atmosphere of the places and times of his early experience and try to let people see the man, and not merely understand him at second hand."28 Holloway had been a fan of the montage technology in D. W. Griffith's The Birth of a Nation (1915), which he would apply to his "narrative" biography. This approach, however, may have had to do as well with Holloway's reticence about Whitman's sexuality, or his fear that its discussion would throw the larger consideration of Whitman and his contribution to world literature out of "balance." A more generalized if not exactly impressionistic picture of the life would tend to minimize the sordid aspects of what Holloway ultimately viewed-in Free and Lone- 
some Heart-as the poet's bisexuality. As he wrote in the biography, he sought "to find the necessary facts and the proper point of view for such a picture of Whitman as would remove him from the field of fruitless controversy, that all that is noble in his poetry and in his example might begin to function in a larger realm than academic and artistic circles." 29 Whereas his Uncollected Poetry and Prose had been an offering to the scholar, his biography was intended for the more general reader. As a consequence, it had no documentation, though I have been able to trace many of its sources to his Uncollected Poetry and Prose.

Holloway did, of course, ignore the Valentine version of "Once I Pass'd through a Populous City" as well as skirt generally the question of Whitman's sexual orientation. This approach probably helped him win the Pulitzer Prize for biography in 1927-his was the first book about a major literary figure to win a Pulitzer. ${ }^{30}$ In researching this essay, I also asked Gay Wilson Allen for his reminiscences of Holloway - to whom Allen wrote as a graduate student at the University of Wisconsin. ${ }^{31}$ On March 8, 1993, Allen wrote me: "Emory Holloway was indeed a pioneer Whitman scholar. His UPP volumes were invaluable to me. . . . But he lost his nerve about some of the sex poems when he wrote the biography." Allen added that Holloway probably would not have won the Pulitzer "if he had not trimmed his sails." 32 Holloway's reluctance was also mentioned in the New York Times review of his biography on October 16, 1926. Although Herbert S. Gorman praised the book generally (while being careful not to praise Whitman too much), he complained that "no true interpetation of Walt Whitman can be made without a due consideration of the man's curious nature as exemplified in the 'Calamus' poems, and here, it is to be suspected, Professor Holloway is unduly reticent." Howard Mumford Jones in the New York Herald Tribune of November 7 was more appreciative of Holloway's achievement. Holloway, he said, "must be counted among those who love Whitman not too well, but very wisely."

Yet Holloway may have loved Whitman too much. In 1916 he had told Saunders: "Perhaps when I have worked on Whitman ten years more I shall think of him less as a man and more of a genius." 33 It was, I think, Holloway's willed optimism about Whitman, his determination to see the poet before the man, that characterizes his achievement in Whitman: An Interpretation in Narrative. For this, as I said, he won the Pulitzer Prize in 1927. And like too many winners of this coveted award, his career came almost to a halt. At the age of forty-one Holloway's best work as a biographer and a Whitman scholar was behind him. He had written the first biography that was almost totally free of the influence of Whitman or his disciples. And he had produced the first informed and detailed discussion of Whitman's "foreground" (his career as a journalist) in The Uncollected Poetry and Prose. 
Of course, he continued to publish on Whitman by returning to discovering discarded poetry and new shreds of Whitman journalism. ${ }^{34}$ Throughout his career, Holloway published hardly anything on a subject other than Whitman. And even this effort was essentially finished by the mid 1930s, when Professor Holloway met the fate of perhaps not enough good scholars and became a college administrator. Yet his scholarship in both the Uncollected Poetry and Prose and the biography stimulated Whitman studies and sent it in new directions. In 1929 Jean Catel's La Naissance du Poète psychoanalyzed the poet's early writings to discover that the nearest thing to truth about Whitman and Leaves of Grass was to be found in the first edition. In 1933 the Danish scholar Frederik Schyberg published his Walt Whitman (translated into English in 1951 by Evie Allison Allen), which probed the poet's life by offering a textual analysis of the various editions. Schyberg dismissed the idea of a New Orleans romance and maintained that if there was a romantic liaison-heterosexual or homosexual-it came in the late 1850s and was directly reflected in the third edition of Leaves of Grass (1860). In 1937 Edgar Lee Masters, whose psychological naturalism in Spoon River Anthology (1915) had made him famous, spoke frankly about Whitman as a "Uranian." The next year Newton Arvin, a scholar at Smith College and a closeted homosexual, attempted to soften Masters' emphasis on sexual pathology by reissuing Holloway's thesis that the "core of abnormality in Whitman's emotional life" did not represent "the whole of his nature" (Whitman, 1938). In 1943 Henry Seidel Canby in Walt Whitman: An American celebrated Whitman as a patriot-his thesis no doubt influenced by the trying years of World War II. "With all its admirable insights," Gay Wilson Allen concludes, "Canby's book is unsatisfactory because he concludes, finally, that intimate details of Whitman's physical life are far less important than his life of imagination and artistic creation., 35

The other two important biographies which appeared before Free and Lonesome Heart are well known and perhaps need no description for the purposes of this essay. Asselineau's The Evolution of Walt Whitman (1954; translated into English in 1960, 1962) discussed Whitman's homosexuality as a primary source of his becoming a poet (by writing himself out of the lifelong anxiety and loneliness that haunted him). Allen's The Solitary Singer (1955) accomplished for the first time-in much more detail and with a half century more of biographical information-what Binns had done for Whitman. And that was to tell the life from start to finish; not only was it as "definitive" in biographical facts, but it presented a critical reading of the poetry. Allen and Asselineau essentially agreed on the major questions - had in fact been neighbors in Oradell, New Jersey, as they completed their respective biographies. Allen was less direct on the homosexuality issue, writing as 
he was in the Eisenhower years. "We agree," Allen wrote of himself and Asselineau on the homosexual issue, "that Whitman was more erotically aroused by men than women, but that clear evidence of his homosexual life is lacking. For this reason I label his sexual emotions as homoerotic, whereas Asselineau uses the unequivocal term homosexual, which is commonly interpreted to imply pederasty or other aberrant sexual practices." Allen adds that "Perhaps today [1975] these distinctions are less important than they seemed in the decade of the 1950s." 36 I have known Gay Allen for more than twenty years, and I think he has told me more than once that he now believes that Whitman was a homosexual in the full and up-to-date definition of the term.

What is true, however, is that just as there is no prima facie evidence that Whitman had an affair with a woman in New Orleans in 1848 so is there no definitive evidence that Whitman was-to revive momentarily the distinction between "homosexual" and "homoerotic" -a practicing homosexual instead of someone drawn inexplicably but not actually towards another of the same sex. This observation is no more or less credible today than it was in the late 1950s when Emory Holloway came out of retirement as a Whitman scholar to write-as a prelude to Free and Lonesome Heart-another biography of the poet. We cannot be sure just when he began the work, but he had a typescript approaching five hundred pages completed by 1959, now deposited in the Brooklyn Public Library. Apparently unsuccessful in finding a publisher for the work, he deposited the completed two-volume bound and indexed typescript of the biography entitled "Portrait of a Poet: A Life of Walt Whitman" in the Berg Collection of the New York Public Library in 1962, and ultimately he settled for reissuing his 1926 biography with a new preface. ${ }^{37}$

In the introduction to his unpublished biography, Holloway stated that "If the earlier biography was a narrative, the present one ... is deliberately expository." As such it is a standard retelling of the poet's life, well written for the most part and showing Holloway's old spark of appreciation for the poet. It is a "sanitized" life-as its epigraph from Whitman on Poe suggests: "By common consent there is nothing better for man or woman than a perfect and noble life, morally without flaw." There is also Holloway's contextualizing of the homosexual elements suggested in the additional statement, quoting from Whitman on Poe, that "there is another shape of personality dearer far to the artist-sense," meaning obviously Whitman's "perturbations," which were supposedly overcome after the 1860 edition. Truly "new" in Holloway's unpublished biography are the three appendices on "Whitman's Disputed Paternity," "John Whitman Wilder," and "A Disputed Journey," the third reviving and updating Holloway's original assertion that Whitman made more than one trip to New Orleans in the late 1840s. Speaking in 
the preface of "several important problems on which agreement has not yet been reached," Holloway calls attention to the presence of his appendices, which he says, are "appendices in name only" (ix). In other words, as late as 1962, Holloway was still not comfortable with making the homosexual question part of the biography proper; nor was he exactly at ease in discussing at that late date the poet's possible liaisons with either low women or women to whom Whitman was not legally linked.

The three appendices, therefore, became the basis and thrust of Free and Lonesome Heart; the rest of this volume is somewhat engaging but biographically superfluous. Indeed, the dustjacket description focuses attention on a single question: "Fust what was the poet's emotional type?" Given the importance of the appendices in the rewritten biography and the thrust of Free and Lonesome Heart, I suspect that Holloway first thought to revise his thesis following the publication of The Solitary Singer. Malcolm Cowley's statement in his review of Allen's biography in the New York Times that "No trace" of Whitman's six illegitimate children had ever been found and Mrs. Greene's insistence that there was "one trace" set back into biographical motion this native of the "show-me" state.

Although Holloway asserted several possibilities for Whitman's having a sexual relationship with a woman in Free and Lonesome Heart (including the publication of a tintype of the Creole woman in New Orleans, that I suspect is a picture of the poet's sister, Hannah Louisa Whitman), he focused ultimately on Whitman's Washington years, very possibly because Mrs. Greene's letter to Allen had suggested that John Whitman Wilder was born around 1869. Soon after Holloway's book appeared in 1960, the Whitman collector Charles E. Feinberg produced a letter that suggested that this was the child of Nancy Whitman, the streetwalking wife of Andrew Jackson Whitman, who died in 1863. The letter is quoted in Joann P. Krieg's essay from Holloway's files but cannot now be located in the Feinberg Collection of Whitman at the Library of Congress. ${ }^{38}$ As Krieg reports, Holloway was skeptical of the letter's authenticity-claiming that Feinberg had never mentioned the letter to him and (more important for our purposes here) that "it was incongruous that a woman who came from a good family would produce a letter of such 'uneducated' quality.",39

Holloway is referring to the Greene family, whose inlaw Victor Wilder was the brother of the two "spinsters" who raised John Whitman Wilder. Mrs. Ruth Greene, as Holloway notes in his book, was a fairly well educated woman of eighty-eight years whose son Richard L. Greene was an internationally recognized scholar of medieval studies at Wesleyan University. In fact, at one point during Holloway's correspondence with her, Mrs. Greene insisted on the return of a letter which she 
feared might offend the Wilder family members if it was quoted in the book Holloway was surely planning. Her son dissuaded her from the request by arguing that it would be good for the world and Whitman if the lingering stories about his homosexuality could be put to rest once and for all. Though educated and witty, Mrs. Greene was apparently a lonely woman who craved intellectual company. She often hinted in her correspondence that she sought to know Holloway more personally and at one point simply asked for "an autobiographical paragraph." 40 More significantly, in another letter to him, Mrs. Greene made a small confession that may have been more than rhetorical: "I have a 'sense of guilt' as the psychologists say," she told Holloway, "to have started such a bothersome train of research. Mr. Allen's book was out, and I wrote him just for fun, with no thought of starting any activity. It has roadblocked your re-editing of your Whitman biography. I said to Richard once, 'Mr. Holloway should hate me!" "41

Holloway ignored the significance of her statement, saying merely that at his age and being retired he had "more time than anything else." $42 \mathrm{He}$ continued to look for more evidence and finally became convinced that Wilder was Whitman's son when he found a newspaper account of the Camden funeral which listed among those who had either brought or sent flowers the name of John Whitman Wilder. ${ }^{43}$ Unfortunately, Holloway, who outside of his Pulitzer-Prize winning biography documented everything, fails to give the citation for this newspaper report, although he did mention the discovery to Mrs. Greene in his letter of March 29, 1957. Of course, Wilder's attendance at the funeral would not have established Whitman's paternity any more than evidence of the poet's having had sex with women would establish him as an exclusive heterosexual. Yet it would establish or strongly suggest a family connection between Wilder and Whitman.

The Feinberg letter suggesting that Wilder was the son of Nancy Whitman put Holloway in a worse dilemma than he had experienced since 1917 when he was first disappointed that his poet had gone with low women and then that he might have been homosexual. For his best response to the Feinberg letter was that "If John was one of the twins born to Nancy the streetwalker, he was not Walt's nephew, though he could have been his son." In other words, to save Whitman from the charge of homosexuality, he had now to entertain the possibility that Whitman had had sexual relations with his sister-in-law, the widow of his brother, and a streetwalker! "I do not wish to say that I believe he was," Holloway added, "but he could have been." 44 Nancy Whitman, nee Nancy McClure,${ }^{45}$ kept up with the family for many years. At first the Whitmans (or Walt and his mother) were worried about Andrew's children, who were said to have been reduced to begging in the streets. Soon after Andrew's death, Nancy gave birth to a son named Andrew, 
who was run over by a brewery wagon in 1868 . Not long afterwards, Mrs. Whitman informed Walt that Nancy had given birth to "twins one dead." 46 The survivor may have been John Whitman Wilder. Whitman wrote to Nancy as late as January 22, 1879, receiving a postcard response two days later. ${ }^{47}$ John Whitman Wilder, if that was her son, would have been ten years old. In a will dated June 29, 1888, Whitman left "Mrs. Nancy Whitman, my brother Andrew's widow, fifty dollars (\$50)." ${ }^{\text {"48 }} \mathrm{He}$ left nothing (directly) to John Whitman Wilder.

Here the Holloway-Whitman trail ends. In one sense, it concludes where it began-with Holloway's first suspicion that the rumors of Whitman's homosexuality might be true. Perhaps he rued the day he ever came upon the Valentine manuscript of "Once I Pass'd through a Populous City" in 1917. Within a week of the discovery, he told Saunders, "Yes, I fancy Bertz would let out a self-righteous 'I told you so' if he had my data on 'Once I Passed . . .' But nobody gets them [i.e., his findings] until I have indisputable proof of [the manuscript's] existence in my possession." 49

Holloway honestly believed that he was in search of the truth, and as early as 1917 he admitted to Saunders that he was convinced that Whitman had been bisexual: His fear was that this fact would be sensationalized to the point that the larger greatness of Leaves of Grass would be eclipsed by the poet's abnormal sexuality. This would have been unfair to Whitman, who, as Holloway pointed out to Saunders, had determined in one of his notebooks to "repress the adhesive nature." Indeed, if the many centennial conferences held around the nation, if not abroad, in 1992 are an indication, Holloway's worst fears have come true. That is to say, most of the American conferences emphasized the poet's homosexuality at the expense of his poetry (which is different from examining the homosexuality as a means to understanding the poetry rather than as an end). This is not to say that Holloway did not wish Whitman completely heterosexual. In defending himself against thinking Whitman homosexual because of the growing popularity of Bertz's theory, he told Saunders that he ardently wished with his friend that "specialists" such as Bertz were proved wrong: "Only, they haven't been as yet; and what is more, they have hardly had a hearing in America. I myself have never yet read Bertz, except excerpts in translation; so he is not responsible for my attitude at all. And as to prejudice, if I had any it was all in favor of the opposite theory when I began my researches." 50 


\section{NOTES}

1 Joan P. Krieg, "Emory Holloway's Final Word on Whitman's Son," Walt Whitman Quarterly Review 10 (Fall, 1992), 74-80. For Bertz, see his Der Yankee-Heiland (Dresden: Carl Reissner, 1905).

2 R[ufus]. Emory Holloway to Henry B. Saunders, January 18, 1917. These letters, both autograph and typed signed, are in the Brooklyn Public Library, where I would like to thank Mr. Monte Olenick, Head of the Language and Literature Division, for his assistance. I would also like to thank Professor Sherry Ceniza of Texas Tech University for calling the letters to my attention and Professor William J. Scheick of the University of Texas at Austin for his help in obtaining Holloway's master's thesis.

3 "Walt Whitman in New Orleans," Yale Review 5 (October, 1915), 166-183.

4 Henry Bryan Binns, A Life of Walt Whitman (London: Methuen \& Co., 1905), 51.

5 Edwin Haviland Miller, ed., Correspondence of Walt Whitman (New York: New York University Press, 1969), 5:73.

6 Holloway to Mrs. Ruth L. (Jas. G.) Greene, March 19, 1956. Henry W. and Albert A. Berg Collection, New York Public Library.

7 Emory Holloway, Whitman As a Subject for Biography (Key Biscayne, Florida: The Kindle Press [privately printed]), 1974, 21.

8 Roger Asselineau, "Walt Whitman, Child of Adam? Three Unpublished Letters to Whitman," Modern Language Quarterly 10 (March, 1949), 91-95. Asselineau's letter and the one dated April 8, 1993, are in my possession.

9 Emory Holloway, "Walt Whitman's Love Affairs," The Dial 69 (November, 1920), 473-483; 477.

10 Holloway to Saunders, February 20, 1917 (Brooklyn). This version of "Once I Pass'd through a Populous City" was in the possession of Patrick A. Valentine of New York. The manuscript is now in the Valentine-Barrett Collection of Walt Whitman at the University of Virginia.

11 Arthur Golden, ed., Leaves of Grass: A Textual Variorum of the Printed Poems (New York: New York University Press, 1980), 2:378.

12 Emory Holloway, Whitman: An Interpretation in Narrative (New York: Alfred A. Knopf, 1926), 172-173.

13 Emory Holloway, ed., Uncollected Poetry and Prose of Walt Whitman (New York: Peter Smith, 1932), 2:102n.

14 Emory Holloway, Free and Lonesome Heart: The Secret of Walt Whitman (New York: Vantage Press, 1960), 54-55.

15 Holloway to Mrs. Greene, March 19, 1956 (Brooklyn).

16 Holloway to Saunders, July 24, 1915 (Brooklyn).

17 Holloway to Saunders, September 12, 1916; and October 21, 1916 (Brooklyn). Holloway wrote a poem (also at the Brooklyn Public Library) about the experience:

There came to me an hour

In which I was divine; 
Time was not, nor any care-

Only the Soul, and the things of the Soul-

Nothing too great to do, naught to evil to love.

A glory from out the Temple of Me painted the earth in splendor, refined and impartial.

The secret of things I felt, but felt not any longing to see.

All things into the One were rolled,

And I of that One a Portion.

18 Holloway to Saunders, October 10, 1920 (Brooklyn).

19 Whitman As a Subject for Biography, 25.

20 Free and Lonesome Heart, 55.

21 Holloway to Saunders, March 4, 1920 (Brooklyn).

22 Rufus Emory Holloway, "The Feeling for Nature in American Poetry," M.A. Thesis, University of Texas, 1912.

23 Ed Folsom pointed out to me the explicit correspondence between Traubel and Gustave P. Wiksell, an officer of the Walt Whitman Fellowship. See the Papers of Gustave P. Wiksell and the Papers of Horace L. and Anne Montgomery Traubel, Library of Congress.

24 Holloway to Saunders, April 18, 1935 (Brooklyn). See Henry S. Saunders, ed., A Whitman Controversy: Being Letters Published in Mercure de France 1913-1914 (Toronto: privately published, 1921). The debate was set off by Guillaume Appollinaire's published letter of April Fool's Day, 1913, quoting eyewitnesses that "pederasts came in crowds" to Whitman's funeral.

25 Walt Whitman: The Correspondence (New York: New York University Press, 1961), 1:93.

26 Correspondence, 1:90-91n.

27 Correspondence, 5:72-73.

28 Holloway to Saunders, October 23, 1921 (Brooklyn).

29 Whitman: An Interpretation in Narrative, xi.

30 William Over, "Emory Holloway," Dictionary of Literary Biography: American Literary Biographers (Detroit: Gale Research, Inc., 1991), 103:163-167.

31 Holloway's corrective notation to a letter to him from Mrs. Ruth L. Greene, December 12, 1956 (Berg).

32 Letter in author's possession.

33 Holloway to Saunders, August 31, 1916 (Brooklyn).

34 Pictures: An Unpublished Poem (1927); Franklin Evans; or the Inebriate (1929); I Sit and Look Out: Editorials from the Brooklyn Daily Times (1932); New York Dissected (1936).

35 Gay Wilson Allen, The New Walt Whitman Handbook (New York: New York University Press, 1975), 55.

36 The New Walt Whitman Handbook, 57.

37 Whitman: An Interpretation in Narrative (New York: Biblo and Tannen, 1969). 
38 Krieg, 76.

39 Krieg, 77.

40 Mrs. Ruth L. Greene to Emory Holloway, December 12, 1955 (Berg).

41 Greene to Holloway, October 28, 1955 (Berg).

42 Holloway to Greene, November 11, 1955 (Berg).

43 Free and Lonesome Heart, 157.

44 Krieg, 77.

45 Jerome M. Loving, ed., Civil War Letters of George Washington Whitman (Durham: Duke University Press, 1975), 12n.

46 Louisa Van Velsor Whitman to Walt Whitman, December 14, 1868 (Josiah P. Trent Collection, Duke University Library).

47 The Correspondence, 3:432, 444.

48 Horace Traubel, With Walt Whitman in Camden (Boston: Maynard \& Company, 1906), 1:312.

49 Holloway to Saunders, February 25, 1917 (Brooklyn).

50 Holloway to Saunders, June 3, 1917 (Brooklyn). 